\title{
Analisis Strategi Penghimpunan Zakat, Infaq Dan Dana Sosial Pada KBMT Dana Akhirat Arjasari Banjaran Bandung
}

\author{
Agustini Solihatin $^{1)}$, Rima Elya Dasuki ${ }^{2)}$, Nanang Sobarna ${ }^{3)}$ \\ Prodi Ekonomi Syariah Institut Manajemen Koperasi Indonesia ${ }^{1}$ ) \\ Institut Manajemen Koperasi Indonesia ${ }^{2), 3)}$ \\ solihatinagustini1@gmail.com \\ rimadasuki@ikopin.ac.id \\ nanangsobarna85@gmail.com
}

\begin{abstract}
ABSTRAK
Penghimpuan zakat, infaq dan dana sosial merupakan salah satu fungsi sosial yang ada di koperasi syariah. Upaya yang dapat dilakukan untuk mengimplementasikan fungsi sosial di koperasi syariah tentu harus adanya penghimpunan yang baik, agar tersalurkan sesuai dengan yang disyariatkan islam dan seluruh masyarakat yang membutuhkan dapat merasakan manfaat yang maksimal dari koperasi syariah. Selian itu, masyarakat sekitar dapat menitipkan atau menyisihkan sebagian pendapat lebih mereka untuk zakat, infaq dan dana sosial yang akan disalurkan kembali oleh koperasi syariah kepada masyarkat yang berhak menerimanya dengan kepercayaan penuh. Dengan itu, adapun tujuan dari penelitian ini yaitu untuk mengetahui gambaran dari strategi penghimpunan dan peluang serta tantangan dalam penghimpunan zakat, infaq, dan dana sosial di KBMT Dana Akhirat Arjasari Banjaran Bandung. Metode penelitian yang digunakan adalah studi kasus dengan analisis data secara deskriptif dengan pendekatan kualitatif dimana dapat diperoleh melalui informan dan dokumen dengan teknik pengumpulan data melalui observasi, wawancara, dan studi pustaka untuk dapat mendeskripsikan penghimpunan serta peluang juga tantangan dalam penghimpunan zakat, infaq dan dana sosial. Hasil penelitian mengenai analisis strategi penghimpunan zakat, infaq dan dana sosial yang dilakukan sudah sesuai syariat islam tetapi masih mengoptimal kan dari pihak internal saja dan masih belum memilki divisi baitul maal bagian khusus dalam pengelolaan zakat, infaq dan dana sosial. Selanjutnya dalam menghadapi tantangan dalam penghimpunan zakat, infaq dan dana sosial, Koperasi BMT Dana Akhirat Arjasari harus lebih maksimal dalam memanfaatkan peluang dan kekuatan yang dimiliki seperti memiliki banyak anggota dengan beragam profesi, menjalin hubungan baik dengan aparat desa, pengurus masjid dan pesantren, jumlah dana zakat, infaq dan dana sosial cukup besar setiap tahunnya, adanya beasiswa pendidikan bagi anak anggota yang berprestasi, menjalin hubungan baik dengab DISKOP dan UKM Kab. Bandung oleh DEKOPINDA.
\end{abstract}

Kata Kunci : Penghimpunan zakat, infaq, dan dana sosial. 


\begin{abstract}
ABSTRACK
Collection of zakat, infaq and social funds is one of the social functions that exist in sharia cooperatives. Efforts that can be made to implement social functions in sharia cooperatives must of course have a good collection, so that they are distributed in accordance with what is prescribed by Islam and all people in need can feel the maximum benefits from sharia cooperatives. In addition, the surrounding community can entrust or set aside some of their more opinion for zakat, infaq and social funds which will be redistributed by sharia cooperatives to people who are entitled to receive them with full trust. With that, the purpose of this study is to find out the description of the collection strategy and the opportunities and challenges in collecting zakat, infaq, and social funds in KBMT Dana Akhirat Arjasari Banjaran Bandung.The research method used is a case study with descriptive data analysis with a qualitative approach which can be obtained through informants and documents with data collection techniques through observation, interviews, and literature studies to be able to describe the collection and opportunities as well as challenges in collecting zakat, infaq and social funds. The results of the research on the analysis of strategies for collecting zakat, infaq and social funds that were carried out were in accordance with Islamic law but still optimized from internal parties and still did not have a special division of baitul maal in the management of zakat, infaq and social funds. Furthermore, in facing challenges in collecting zakat, infaq and social funds, the BMT Dana Akhirat Arjasari Cooperative must maximize its opportunities and strengths, such as having many members with various professions, establishing good relations with village officials, mosque and pesantren administrators, the amount of funds Zakat, infaq and social funds are quite large every year, there are educational scholarships for children of members who excel, establish good relations with DISKOP and UKM Kab. Bandung by DEKOPINDA.
\end{abstract}

Keywords: Collection of zakat, infaq, and social funds.

\title{
PENDAHULUAN
}

Keberadaan BMT dipandang memiliki memiliki visi dan misi . Visi yang dimiliki oleh BMT yaitu menjadi lembaga keuangan yang mandiri, sehat, dan kuat, yang kualitas ibadah anggotanya meningkat sedemikian rupa sehingga mampu berperan menjadi wakil pengabdi Allah memakmurkan kehidupan anggota pada khusunya dan umat manusia pada umumnya serta misi yang dimiliki oleh BMT sendiri yaitu mewujudkan gerakan pembebasan anggota dan masyarakat dari belenggu rentenir, jerat kemiskinan dan ekonomi ribawi, gerakan pemberdayaan meningkatkan kapasitas dalam kegiatan ekonomi riil dan kelembagaannya menuju tatanan perekonomian yang makmur dan maju dalam gerakan keadilan membangun struktur masyarakat madani yang adil dan bermakmur berkemajuan, serta makmur maju berkeadilan berlandaskan syariah dan ridha Allah SWT (Soemitra,2010).

Koperasi syariah memliki tiga fungsi utama (Rusnee \& Oktafia, 2018) yaitu pertama sebagai manajer Investasi, koperasi syari'ah mampu menjadi seorang manajer investasi dari pemilik dana yang dihimpunnya. Hasil usaha yang baik dari koperasi syari'ah tergantung pada keterampilan,kehati-hatian dan profesionalisme koperasi syariah 
tersebut. Kedua sebagai investor, dana investasi syari'ah dapat dikumpulkan dari beberapa anggota dan pihak lain dengan pola investasi sesuai dengan prinsip syari'ah. Ketiga, sebagai fungsi sosial, koperasi syariah memerlukan penyediaan layanan dan dana sosial untuk anggotanya yang membutuhkan dan bagi masyarakat dhu'afa. Dengan, ketiga fungsi utama yang penting pada BMT tersebut beserta tujuan, visi dan misi yang dimiliki oleh BMT tersebut disebutkan bahwa koperasi syariah atau BMT punya tujuan pokok yaitu untuk mememuhi kesejahteraan masyarakat yang membutuhkan melalui layanan dan dana sosial. Sehingga perlunya strategi pengelolaan zakat, infaq, dan dana sosial yang ada di BMT harus lebih diperhatikan agar terciptanya suatu kesejahteraan yang dapat dirasakan oleh anggota khususnya dan masyarakat (umat islam) sekitar dengan adanya pemberdayaan dana ZIS yang disalurkan dengan tepat sasaran.

Koperasi Baitul Mal Wa Tamwil Dana Akhirat Arjasari Banjaran Bandung adalah koperasi yang kegiatan usahanya bergerak di bidang simpan pinjam dan pembiayaan yang polanya sesuai dengan syariah dan mempunyai orientasi ganda yaitu profit oriented (Baitul tamwil) dan oriented (Baitul Maal), selain bertujuan pada profit/keuntungan, KBMT Dana Akhirat Arjasari Bandung mempunyai fungsi sosial yaitu pada bidang Baitul Maal nya yang melakukan kegiatan penghimpunan dan penyaluran dana zakat, infaq dan dana sosial. Oleh karena itu, dalam penelitian ini akan mendeskripsikan bagaimana pengelolaan zakat, infaq dan dana sosial sebagai imolementasi fungsi sosial koperasi syariah di KBMT Dana Akhirat Arjasari Banjaran Bandung.

\section{PERUMUSAN MASALAH, MANFAAT PENELITIAN, DAN TUJUAN PENELITIAN}

\section{A. Rumusan Masalah}

1. Bagaimana Strategi Penghimpunan Zakat, Infaq dan Dana Sosial di Koperasi Baitul Maal Wat Tamwil Dana Akhirat Arjasari Bandung.

2. Apa Saja Peluang dan Tantangan Dalam Penghimpunan Zakat, Infaq dan Dana Sosial di Koperasi Baitul Maal Wat Tamwil Dana Akhirat Arjasari Bandung.

\section{B. Manfaat Penelitian}

\section{Kegunaan Teoritis}

Teori ini diharpakan dapat memberikan manfaat bagi pengembangan keilmuan di Koperasi Simpan Pinjam Dan Pembiayaan Syariah Baitul Maal Wat Tamwil Dana Akhirat Arjasari dengan memberikan data nyata terhadap ilmu ekonomi syariah yang terkait dengan kinerja keuangan suatu lembaga keuangan syariah, serta memberikan manfaat dari segi keilmuan mengenai manajemen koperasi syariah yang berhubungan dengan ilmu penghimpunan dana ZIS ( Zakat, Infaq, Shadaqah) yang ada di Koperasi Simpan Pinjam Dan Pembiayaan Syariah Baitul Maal Wat Tamwil Dana Akhirat Arjasari sehingga dapat dikelola sebagaimana mestinya.

\section{Kegunaan Praktis}

a. Bagi Peneliti

Hasil penelitian ini dapat dijadikan sebagai rujukan apabila nantinya berkecimpung didalam masyarakat, khususnya dalam strategi pengelolaan dana zakat, infaq, dan dana sosial di Koperasi Simpan Pinjam Dan Pembiayaan Syariah Baitul Maal Wat 
Tamwil Dana Akhirat Arjasari untuk menyelaraskan dengan metode yang digunakan sesuai dengan syari'at Islam.

b. Bagi Koperasi Baitul Maal Wat Tamwil Dana Akhirat Arjasari

Hasil penelitian ini diharapkan dapat menyelesaikan permasalahan serta dapat pula dijadikan sebagai bahan pertimbangan dalam mengambil keputusan dan dapat lebih memperhatikan serta meminimalisir permasalahan yang ada dalam koperasi syariah, khususnya pada strategi pengelolaan dana zakat, infaq, dan dana sosial sebagai implementasi fungsi sosial koperasi di Koperasi Baitul Maal Wat Tamwil Dana Akhirat Arjasari sesuai dengan syariat islam.

c. Bagi Pembaca

Hasil penelitian ini diharapkan dapat memberikan informasi,wawasan, dan gambaran serta kajian penelitian lebih lanjut.

\section{Tujuan Penelitian}

1. Strategi Penghimpunan Zakat, Infaq dan Dana Sosial di Koperasi Baitul Maal Wat Tamwil Dana Akhirat Arjasari Bandung.

2. Peluang dan Tantangan Dalam Penghimpunan Zakat, Infaq dan Dana Sosial di Koperasi Baitul Maal Wat Tamwil Dana Akhirat Arjasari Bandung

\section{TINJAUAN PUSTAKA}

\section{A. Koperasi Syariah}

\section{Pengertian Koperasi Syariah}

Salah satu jenis koperasi syariah sesuai dengan Keputusan menteri adalah Koperasi Simpan Pinjam dan Pembiayaan Syari'ah yang biasanya disebut dengan KSPPS. Dalam pelaksanaannya KSPPS diatur dalam Peraturan Menteri Koperasi Dan Usaha Kecil Menengah Republik Indonesia No. 16 tahun 2015.

Penjelasan mengenai keputusan menteri KUKM Nomor 16 Tahun 2015 tentang pepelaksanaan Kegiatan Usaha Simpan Pinjam Dan Pembiayaan Syari'ah Oleh Koperasi pada BAB I Pasal I ayat (2) menjelaskan bahwa :

“Koperasi Simpan Pinjam dan Pembiayaan Syari'ah selanjutnya dalam peraturan ini disebut KSPPS adalah koperasi yang kegiatan usahanya meliputi simpanan, pinjaman dan pembiayaan sesuai prinsip syari'ah, termasuk mengelola zakat, infaq/shadaqah, dan waqaf".

Selain itu adapun persamaan dan perbedaan dari KSPPS dan juga BMT, menurut (Dasuki, 2018) dalam jurnal penelitiannya menguraikan bahwa semua Baitul Maal Wa Taamwil (BMT) yang ada di Indonesia dapat digolongkan sebagai Koperasi Simpan Pinjam dan Pembiayaan Syariah (KSPPS) yang mempunyai payung hukum yang sama asal memenuhi ketentuan undang-undang yang berlaku pada operasionalnya. Namun adapun perbedaannya yaitu pada lembaganya, pada KSPPS hanya terdiri satu lembaga saja yaitu menjalankan dengan sistem simpan pinjam syariah dan pembiayaan syariah . sedangkan pada BMT terdapat dua lembaga yaitu sesuai dengan arti namanya "Baitul Maal Wa Tamwil" yang berarti sebagai lembaga zakat dan lembaga keuangan syariah. Sehingga, Baitul Maal berarti lembaga zakat dan Baitul Tamwil berarti lembaga keuangan (Syariah). 


\section{Prinsip Koperasi Syariah}

Pada pasal 1 ayat 6 Pertaturan Menteri Koperasi Usaha Kecil Dan Menengah Republik Indonesia No. 16 Tahun 2015 tentang Pelaksanaan KSPPS, berisi tentang :

"Prinsip syariah adalah prinsip hukum islam dalam kegiatan usaha koperasi berdasarkan fatwa yang dikeluarkan oleh Dewan syari'ah Nasional Majelis Ulama Indonesia (DSN-MUI)".

Selain itu, adapun prinsip syariah yang sangat mendasar pada lembaga keuangan syariah yaitu terhindari unsur MAGHRIB (Maysir, Gharar, Haram, Riba, Bathil).

\section{Perbedaan Koperasi Syariah dan Koperasi Konvensional}

Menurut (Ningsih \& Masruroh, 2018) dalam jurnalnya menguraikan beberapa perbedaan dari koperasi syari'ah dan koperasi konvensional, diantaranya sebagai berikut :

a. Pembiayaan : Dalam system pembiayaan koperasi syariah menerapkan sistem bagi hasil kepada nasabahnya yang meminjam sedangkan di koperasi konvensional menerapkan system bunga dengan membebankan kepada para nasabah atau peminjam.

b. Aspek Pengawasan : Pada aspek pengawasan koperasi syari'ah tidak hanya mengawasi kinerja saja tetapi juga mengawasi dari berbagai prinsip pribadi anggota atau karyawan seperti kejujuran dan mengawasi mengenai aliran dana serta pembagian hasil, selain itu pada koperasi syariah memiliki Dewan Pengawas yang sering disebut Dewan Pengawas Syariah (DPS). Sedangkan koperasi konvensional hanya mengawasi pada kinerjanya saja, yang diawasi oleh para petugas dalam mengelola koperasi.

c. Penyaluran Produk : Pada koperasi syariah dalam menyalurkan produk tidak mengkreditkan barang-barangnya, maka transaksi yang terjadi yaitu jual beli atau yang disebut pada koperasi syariah yaitu murabahah, dengan itu uang atau barang yang diberikan kepada nasabah atau peminjam tidak dibebankan bunga tetapi adanya bagi hasil apabila nasabah atau peminjam tersebut mengalami kerugian maka koperasi akan memberikan keringanan dalam pengembalian uangnya. Sedangkan pada koperasi konvensional dalam penyaluran produknya melakukan sistem kredit berupa uang atau barang dan memberikan beban bunga kepada nasabahnya, sehingga jika mengalami kerugian atau keuntungan nasabah harus tetap memberikan dana sebesar yang dipinjamkan dan ditambah dengan bunga yang sudah ditetapkan diawal.

d. Adanya fungsi sosial lembaga zakat pada koperasi syariah sebagai usahanya untuk menghimpun dan menyalurkan dana zakat serta nasabahnya diwajibkan untuk mengeluarkan zakat. Sedangkan pada koperasi konvensional usahanya tidak menrima dan penyalur zakat.

\section{B. Baitul Maal Wa Tamwil}

\section{Pengertian}

Selain itu, di tegaskan kembali menurut (Mardani, 2015) mengatakan bahwa BMT adalah suatu Badan Usaha Mandiri Trerpadu atau dapat dikatakan sebagai lembaga keuangan mikro (LJKM) yang pelaksanaannya berdasarkan prinsip-prinsip 
syariah. Selain itu, BMT juga merupakan suatu lembaga yang mempunyai dua istilah, diantaranya pada dua istilah nama BMT tersebut memiliki dua fungsi sosial utama yaitu :

a. Baitul tamwil (rumah pengembangan harta), fungsi sosialnya yaitu melakukan kegiatan pengembangan usaha-usaha produktif dan investasi dalam meningkatkan kualitas ekonomi pengusaha mikro dan kecil dengan antara lain mendorong kegiatan menabung dan menunjang pembiayaan kegiatan ekonomi. Adapuan sebagai usaha pengumpulan dan penyaluran dana komersial.

b. Baitul maal (Rumah harta), fungsi sosialnya yaitu menerima titipan dana zakat, infaq, dan sedekah serta mengoptimlakan pendistribusiannya sesuai dengan peraturan dan amanahnya.

\section{Peran dan Fungsi}

Menurut (Sudarsono, 2012) menyatakan bahwa selain BMT mempunyai tujuan, visi dan misi. BMT juga mempunyai beberapa peran:

1. Menjauhkan masyarakat dari praktik ekonomi nonsyariah, mampu memberikan isasi di tengah masyarakat tentang arti penting sistem ekonomi islam. Hal tersebut bisa dilakukan dengan pelatihan mengenai cara-cara bertransaksi secara islami, dilarang curang dalam menimbang, jujur pada konsumen dan praktik transaksi lainnya yang sesuai dengan syariat islam.

2. Melakukan pembinaan dan pendanaan usaha kecil bagi masyarakat. Selain itu BMT juga harus bisa menjalankan fungsi sosial sebagai lembaga keuangan mikro, misalnya dengan adanya pendampingan, pembinaan, penyuluhan, dan pengawasan terhadap usaha-usaha nasabah dan masyarakat .

3. Melepaskan masyarakat dari ketergantungan pada rentenir. Masyarakat yang masih tergantung pada rentenir disebabkan rentenir mampu memenuhi keinginan masyarakat dalam memenuhi dana dengan prosedur yang mudah dan cepat. Maka BMT harus mampu melayani masyarakat lebih baik, misalnya selalu menyediakan dana setiap saat, birokrasi yang sederhana, serta pelayanan yang nyaman dan baik.

4. Menjaga keadilan ekonomi masyarakat dengan pendistribusian yang merata. Maka fungsi sosial BMT harus mampu langsung berhadapan dengan masyarakat yang kompleks yaitu dituntut harus pandai bersikap, oleh karena itu langkahlangkah untuk melakukan evaluasi dalam rangka pemerataan skala prioritas yang harus diperhatikan, misalnya dalam masalah pembiayaan, BMT harus memperhatikan kelayakan nasabah dalam golongan nasabah dan jenis pembiayaan.

Menurut (Mardani, 2015) selain memiliki fungsi secara umum, BMT juga memiliki beberapa fungsi sosial secara khusus di masyarakat yaitu :

1. Meningkatkan kualitas SDM anggota, pengurus, dan pengelola menjadi lebih professional, salaam ( selamat, damai dan sejahtera ) dan amanah sehingga semakin utuh dan tangguh dalam berjuang serta berusaha (beribadah) untuk menghadapi tantangan global.

2. Mengorganisasi dan memobalisasi dana sehingga dana yang dimiliki oleh masyarakat dapat memberikan manfaat secara optimal di dalam dan di luar organisasi untuk kepentingan masyarakat banyak dan merata. 
3. Mengembangkan kesempatan kerja.

4. Mengukuhkan dan meningkatkan kualitas usaha dan produk-produk anggota. Memperkuat dan meningkatkan kualitas lembaga-lembaga ekonomi dan social masyarakat banyak serta merata.

\section{Ciri-Ciri}

Baitul Maal Wa Tamwil memiliki beberapa ciri-ciri, ada ciri BMT secara khusus dan ciri secara umum. Menurut (Soemitra, 2015) menguraikan ciri secara utama dan khusus dari Baitul Maal Wa Tamwil.

1. Ciri-Ciri Utama BMT, yaitu :

a. Berorientasi bisnis, untuk mencari laba bersama, dalam meningkatkan pemanfaatan ekonomi yang paling banyak bagi anggota dan lingkungan.

b. Bukan merupakan lembaga sosial tetapi dapat dimanfaatkan untuk mengefektifkan penggunaan zakat, infaq, dan sedekah bagi sejahteraan masyarakat sekitar atau orang banyak.

c. Mulai tumbuh dari bawah berlandasakan peran serta masyarakat di sekitarnya.

d. Milik bersama masyarakat kecil dan bawaha maupun masyarakat besar dari lingkungan BMT itu sendiri, bukan milik orang seorang atau orang dari luar masyarakat tersebut.

2. Ciri-Ciri Khusus BMT :

a. Staf dan karyawan BMT bertindak aktif, dinamis berpandangan produktif, menjemput nasabah, baik sebagai penyetor dana ataupun sebagai penerima pembiayaan usaha.

b. Kantor dibuka dalam waktu tertentu dan di dalamnya terdapat beberapa staf yang terbatas, karena sebagian staf lainnya harus bergerak di lapangan untuk mendapatkan nasabah penyetor dana, memonitor, dan mensupervisi usaha nasabah.

c. BMT yang mengadakan pengajian rutin secara berkala waktu dan tempatnya, baik itu tempatnya di madrasah ataupun di masjid dan mushala yang disesuaikan dengan kegiatan nasabah dan anggota BMT. Setelah pengajian biasanya dilanjutkan dengan diskusi mengenai bisnis dari para nasabah BMT.

d. Manajemen BMT diselenggarakan secara professional dan sesuai syariat islam

\section{Akad dan Produk}

Menurut (Huda \& Heykal, 2015) menyebutkan bahwa pada produk penghimpunan dana lembaga keuangan islam sesuai dengan Himpunan Fatwa DSN-MUI tahun 2003, adalah :

1. Giro Wadiah adalah produk simpanan yang bisa ditarik kapan saja. Dana nasabah yang dititipkan di BMT dan dapat dikelola. Setiap saat nasabah berhak untuk mengambilnya dan berhak mendapatkan bonus dari keuntungan pemanfaatan dana giro oleh BMT. Besarnya bonus tidak ditetapkan di muka tetapi merupakan 
kebijaksanaan BMT. Demikian nominalnya diupayakan sedemikian rupa untuk senantiasa kompetitif (Fatwa DSN-MUI No.01/DSN-MUI/IV/2000).

2. Tabungan Mudarabah, dana yang disimpan nasabah akan dikelola BMT, untuk memperloleh keuntungan. Keuntungan tersebut akan diberikan kepada nasabah berdasarkan kesepakatkan nasabah. Dimana nasabah bertindak sebagai shahibul maal dan lembaga keuangan islanya bertindak sebagai mudharib (Fatwa DSN-MUI No. 02/DSN-MUI/IV/2000)

3. Depositi Mudarabah, BMT bebas melakukan berbagai usaha yangtidak bertentang dengan islam dan mengembangkannya. BMT juga bebas dalam mengelola dana (mudarabah mutaqah). BMT berfungsi sebagai mudharib sedangkan nasabah sebagai shahibul maal. Adapun dana nasabah yang dititipkan untuk usaha tertentu. Namun, nasabah memberikan batasan pada penggunaan dana untuk jenis dan tempat tertentu. Jenis ini disebut dengan mudarabah muqayyadah.

\section{Startegi}

\section{Pengertian Strategi}

Strategi berasal dari kata Yunani yaitu strategeia (stratus = militer; dan $a g=$ memimpin), yang artinya seni atau ilmu untuk menjadi seorang jendral. Namun, strategi juga dapat diartikan sebagai suatu rencana untuk dilakukannya pembagian dan penggunaan kekuatan militer dan material pada daerah-daerah tertentu untuk mencapai tujuan (Sanwani, Herwanti, et al., 2017).

\section{Bentuk-Bentuk Strategi}

Menurut (Sanwani, Titiek Herwanti, et al., 2017) ada beberapa bentuk startegi, diantaranya adalah:

\section{a. Strategi Pemasaran}

Menurut (Assauri, 2013) dalam penelitiannya menyatakan bahwa strategi pemasaran adalah serangkaian tujuan dan sasaran, kebijakan serta aturan dalam memberikan arahan kepada usaha pemasaran perusahaan atau lembaga dari waktu ke waktu, pada masing-masing tingkatan, acuan serta alokasinya, terutama sebagai tanggapan perusahaan atau lembaga dalam menghadapi lingkungan dan keadaan persaingan yang selalu berkembang. Sedangkan menurut Swasta, strategi pemasaran adalah suatu system keseluruhan dari kegiatan usaha melalui perencanaan, penentuan harga, mempromosikan, dan mendistribusikan barang dan jasa yang memuaskan dan memenuhi kebutuan konsumen (Atmoko, 2018). Sedangkan strategi pemasaran menurut pandangan islam menyatakan bahwa dalam bisnis itu harus mengarahkan pada proses penciptaan, penawaran dan perubahan nilai dari seseorang inisiator kepada penlanggannya dengan dilandasai nilai-nilai islam yang dijiwai oleh semangat ibadah kepada Allah dan berusaha semaksimal mungkin untuk kesejahteraan bersama.

\section{b. Strategi Promosi}

Menurut Kotler dan Armstrong menyatakan bahwa promosi (promotion) adalah suatu unsur yang digunakan untuk memberitahukan dan membujuk pasar tentang produk dan jasa yang baru pada perusahaan melalui iklan, penjualan pribadi, promosi penjualan maupun publikasi (Hedynata \& Radianto, 2016). Sedangkan, strategi promosi diterapkan dalam ekonomi islam yaitu untuk menwarkan, menginformasikan, menjual produk atau jasa dipasar dengan prinsip yang 
digunakan oleh Nabi Muhammad SAW adalah personal selling, iklan, promosi penjualan dan humas.

\section{E. Penghimpunan Zakat, Infaq, dan Dana Sosial}

Menurut (Putra, 2019) dalam jurnal penelitiannya menjelaskan bahwa penghimpunan atau pengumpulan dana zakat, infaq dan shadaqah merupakan proses untuk memberitahukan dan mengajak masyarakat (muzzaki) agar dapat melakukan amal kebajikan dalam bentuk penyertaaan dan penyerahan dana sosial untuk diserahkan kepada masyarakat yang membutuhkan demi membantu memenuhi kebutuhan sehariharinya.

\section{F. Zakat, Infaq, dan Dana Sosial}

\section{Zakat}

\section{a. Pengertian Zakat}

Menurut (Mardani, 2015) zakat secara etimologis berarti tumbuh, berkembang, subur, bertambah, menyucikan, dan membersihkan. Adapun secara terminologys, zakat, menurut istilah fikih berarti "sejumlah harta tertentu yang diwajibkan Allah diserahkan kepada orang-orang yang berhak," di samping itu berararti "mengeluarkan jumlah tertentu itu sendiri".

\section{b. Syarat dan Rukun Zakat}

Menurut (Gumilang, 2020) Ada beberapa mengenai syarat dan rukun zakat. Berikut beberapa syarat zakat, sebagai berikut :

1. Islam : Zakat ialah wajib bagi umat beragama islam tanpa terkecuali, karena sudah jelas terdapat pada rukun islam bahwa zakat itu kewajiban bagi seorang muslim. Ada dua pandangan dalam berzakat, menurut ijma' zakat tidak wajib bagi orang kafir karena zakat merupakan ibadah mahdah (perbuatan yang sudah ditentukan syarat dan rukunnya). Sedangkan menurut mzhab Imam Syafi'i, mengatakan bahwa seseorang yang murtad wajib mengeluarkan zakat dari hartanya sebelum riddah-nya terjadi, yaitu ketika harta yang dimilikinya ketika mereka masih menjadi seorang muslim.

2. Merdeka : zakat yang dikarenakan untuk mereka yang bebas dan mereka yang bisa bertindak bebas. Pada hakikatnya, zakat memang hanya diwajibkan untuk harta yang dimiliki sendiri secara penuh.

3. Baligh dan Berakal : Menurut Madhzab Syafi'i mengsyaratkan bagi mereka yang menunaikan zakat itu wajib baligh dan berakal. Anak kecil dan orang gila tidak diwajibkan untuk mengeluarkan ataupun menunaikan zakat. Tetapi, dapat dilakukan oleh wali yang mengelola hartanya dan diwajibkan untuk mengeluarkan zakatnya karena kewajiban zakat berhubungan dengan hartanya. Karena, hukum zakat menurut islam merupakan wajib ain, jadi bayi yang baru saja lahirpun sudah diwajibkan untuk menunaikan zakat dengan tanggungan orang tuanya.

4. Mencapai nishab : Nisab adalah batas minimal wajib zakat pada harta yang wajib dizakati. Selin itu nisab itu merupkan sejumlah harta yang mencapai jumlah tertentu yang ditentukan secara hukum, jadi juka ukuran harta kurang dari ukuran tersebut tidak wajib dizakati. (Fahrur, 2011). Ditegaskan kembali menurut (Nurjamil \& Nurhayati, 2020) dalam jurnal penelitiannya menjelaskan 
bahwa nishab zakat merupakan jumlah minimal yang ditetapkan pada harta masing-masing yang dimilki yang telah dikenakan zakat dengan berbeda-beda nilainya, hal tersebut sesuai dengan jenis zakat yang ditetapkan. Seperti halnya zakat penghasilan, maka kadar zakat yang ditetapkan adalah 2,5\%. Pada Nishab zakat penghasilan tersebut ditetapkan juga sebesar 85 gram emas.

Sedangkan rukun zakat merupakan unsur-unsur wajib yang wajib terpenuhi sebelum mengerjakan zakat karena zakat merupakan suatu ibadah. Berikut beberapa rukun zakat :

1. Niat :Suatu maksud yang harus diiringi dengan perbuatannya (perilaku). Karena zakat tergolong sebagai ibadah, jadi niatnya harus disertai dengan pelaksanaannya.

2. Tamlik: Tamlik adalah harta zakat yang harus dilepaskan dan diberikan kepada para mustahiq (Zuhaily, 2010).

\section{c. Dasar Hukum Zakat}

Dasar hukum dan kewajiban zakat terdapat dalam beberapa firman Allah SWT dan beberapa Hadis Nabi Muhammad SAW . Berikut dail-dalil dari Al-Qur'an sebagai berikut :

1. Firman Alllah SWT dalam QS. At-Taubah : 103

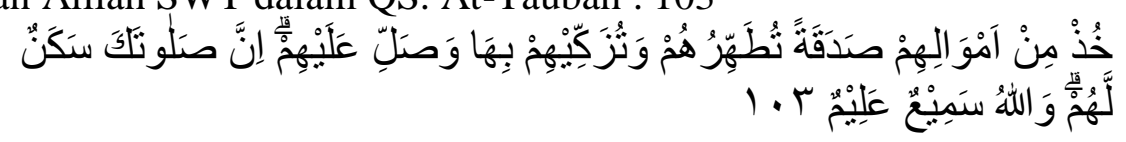

Artinya :"Ambillah zakat dari harta mereka (guna) menyucikan dan membersihkan mereka, dan doakanlah mereka karena sesungguhnya doamu adalah ketenteraman bagi mereka. Allah Maha Mendengar lagi Maha Mengetahui".

2. Firman Allah SWT dalam QS. Al-Baqarah : 43

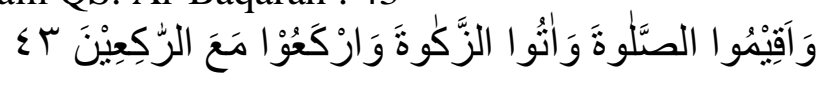

Artinya : "Tegakkanlah salat, tunaikanlah zakat, dan rukuklah beserta orangorang yang rukuk"

\section{d. Asas Pengelolaan Zakat}

Menurut Pasal 2 UU No. 23 Tahun 2011 tentang Pengelolaan Zakat Pengelolaan zakat berasaskan pada :

1. Syariat islam.

2. Amanah.

3. Kemanfaatan. Asas "Kemanfaatan" adalah pengelolaan zakat dilakukan agar mampu memberikan manfaat bagi mustahiq.

4. Keadilan. Maksud dari "Keadilan" adalah dalam pengelolaan zakat untuk pendistribusiannya dapat dilakukan secara adil.

5. Kepastian Hukum. Maksud dari asas "Kepastian Hukum" adalah dalam pengelolaan zakat terdapat jaminan kepastian hukum bagi para mustahiq dan muzzaki. 
6. Terintegrasi. Maksud dari asas "Terintegrasi" adalah pengelolaan zakat dilakukan secara hierarkis dalam upaya meningkatkan pengumpulan, pendistribusian, dan pendayagunaan zakat.

7. Akuntanbilitas. Maksud dari asas "Akuntanbilitas" adalah pengelolaan zakat dapat dipertanggung jawabkan dan diakses oleh masyarakat.

\section{e. Pendistribusian Zakat}

Zakat dapat didistribusikan kepada mustahiq sesuai dengan syariat islam. Yang termasuk mustahik berdasarkan QS. At-Taubah (9): 60 :

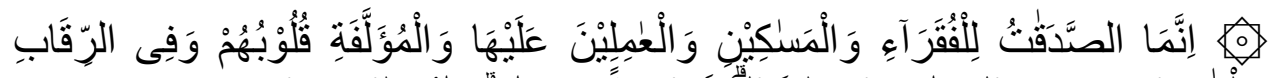

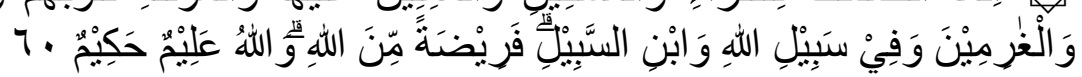

Artinya : "Sesungguhnya zakat itu hanyalah untuk orang-orang fakir, orangorang miskin, para amil zakat, orang-orang yang dilunakkan hatinya (mualaf), untuk (memerdekakan) para hamba sahaya, untuk (membebaskan) orang-orang yang berutang, untuk jalan Allah dan untuk orang-orang yang sedang dalam perjalanan (yang memerlukan pertolongan), sebagai kewajiban dari Allah. Allah Maha Mengetahui lagi Mahabijaksana”.

Berdasarkan tafsir Kemendag oleh Kementrian Agama RI sesuai dengan isi dari ayat At-taubah tersebut menjelaskan mengenai siapa saja orang yang berhak mendapatkan zakat, yaitu diantaranya : orang fakir, orang miskin, penguruspengurus zakat (amil), mualaf, budak, gharimin, sabilillah, Ibnu Sabil.

\section{Infaq}

\section{a. Pengertian Infaq}

Kata infaq berarti mendermakan harta yang diberikan Allah SWT, menafkahkan sesuatu pada orang lain semata-mata mengharap ridha Allah SWT. Dengan demikian, infaq merupakan bentuk pentasharrufan harta sesuai dengan tuntunan syariat (Budiman, 2012).

\section{b. Dasar Hukum Infaq}

Berikut, dasar hukum infaq yang telah banyak dijelaskan baik dalam Al-Qur'an atau hadist :

1. Q.S. Adz-Dzariyat (51) : 19

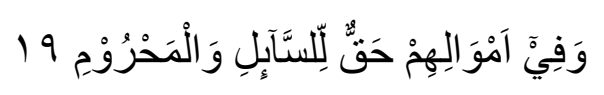

Artinya : "Pada harta benda mereka ada hak bagi orang miskin yang meminta dan yang tidak meminta".

2. Q.S. Al-Baqarah : 3

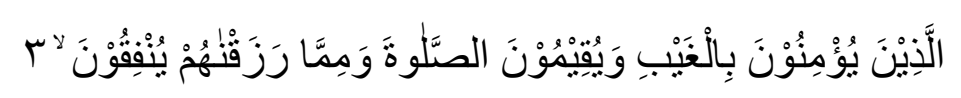

Artinya : "(yaitu) orang-orang yang beriman pada yang gaib, menegakkan salat, dan menginfakkan sebagian rezeki yang Kami anugerahkan kepada mereka”.

\section{c. Golongan Yang Berhak Mendapatkan Infaq}

Infaq dapat dikeluarkan oleh setiap orang yang beriman dan tidak mengenal nishab seperti zakat, sehingga siapapun dapat berinfaq maupun berpenghasilan tinggi ataupun 
rendah yang penting mempunyai niat untuk berinfaq karena Allah untuk menyisihkan sebagian harta yang dimiliki tanpa adanya batsan nominal. Jika zakat memang diwajibkan untuk diberikan kepada mustahik tertentu (8asnaf) maka infaq boleh diberikan kepada siapapun, seperti kepada orangtua, kerabat dekat, anak yatim, anak asuh, pada pembangunan masjid dan kegiatan lainnya. Dalam Al-qur'an dijelaskan golongan siapa saja yang berhak menerima infaq yaitu pada QS. Al-Baqarah ayat 215 :

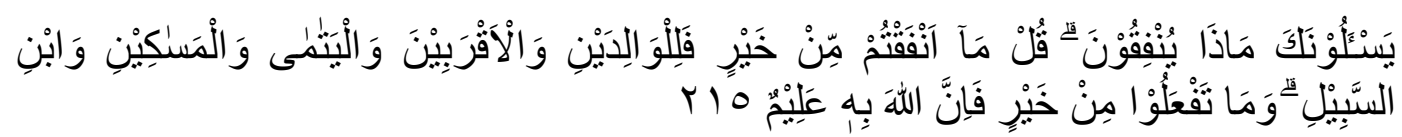

Artinya : "Mereka bertanya kepadamu (Nabi Muhammad) tentang apa yang harus mereka infakkan. Katakanlah, "Harta apa saja yang kamu infakkan, hendaknya diperuntukkan bagi kedua orang tua, kerabat, anak-anak yatim, orang-orang miskin, dan orang yang dalam perjalanan (dan membutuhkan pertolongan)." Kebaikan apa saja yang kamu kerjakan, sesungguhnya Allah Maha Mengetahuinya".

\section{Dana Sosial}

\section{a. Pengertian Dana Sosial}

Menurut (Rawla et al., 2018) dana adalah suatu materi seperti uang yang disediakan oleh donatur atau dikumpulkan untuk suatu tujuan tertentu, sedangkan sosial adalah suatu kegiatan yang dibangun dan dilakukan salam suatu komunitas. Maka dalam hal ini dana sosial yang dimaksud adalah suatu bentuk materi berupa uang yang dikumpulkan dengan tujuan untuk membangun kelompok tertentu yang membutuhkan sererti kaum dhuafa, fakir miskin menjadi sejahtera dan terpenuhi kebutuhannya.

\section{b. Sumber Dana Sosial}

Menurut (Siti, 2019) dalam penelitiannya menyebutkan pada koperasi syariah atau BMT dan lembaga keuangan syariah lainnya memilki dana sosial ataupun dana kebajikan. Dana tersebut berasal dari Ta'zir. Ta'zir adalah sanksi yang dikenakan kepada nasabah atau bagi nasabah yang terlambat dalam pembayaran yang telah dilakukannya, sehingga dana ta'zir yang diterima tersebut masuk kedalam dana sosial BMT bukan masuk kepada pendapatan.

\section{G. Implementasi Fungsi Sosial Koperasi Syariah}

Menurut (Yuditya, 2015) dalam jurnalnya mengatakan bawa dari kedua pengertian mengenai aspek BMT dapat disimpulkan bahawa BMT memiliki dua fungsi sekaligus yang sangat berkaitan dalam lembaga ekonomi masyarakat, yaitu fungsi sosial dan fungsi komersial. Hal ini dikarenakan bahwa BMT memang jelas memilki dua istilah tersebut, diantaranya Baitul maal (Fungsi Sosial) yang merupakan istilah dalam organisasi yang mengumpullkan dan menyalurkan dana non profit, seperti zakat, infaq, shadaqah. Pada fungsi sosial ini BMT mempunya tujuan untuk kesejahteraan anggota dan masyarat lingkungannya dengan menerapkan konsep hahl dan syariah serta menghilangkan ekonomi ribawi. Sedangkan dari sisi Baitul tamwil (Fungsi Komersial) kegiatanya mengumpulkan dan menyalurkan dana komersial, seperti tabungan, pinjaman, dan transaksi ekonomi yang bersifat produktif untuk menghasilkan keuntungan atau laba. Kedua fungsi sosial pada BMT ini tidak bisa dipisahkan, jika salah satunya terjadi pengingkaran maka akan berakibat fatal secara negative pada keutusan jati diri BMT. 


\section{Perbedaan Fungsi Sosial dan CSR}

Menurut, (Nafik, M. dan Fauzy, 2015) dalam jurnal penelitiannya menyebutkan bahwa terdapat dua perbedaan secara signifikan antara fungsi sosial dan CSR (Corporate Social Responsibility), diantaranya :

1. Corporate Social Responsibility (CSR)

a. Pada akhir abad ke-19 : Beberapa perusahaan besar menyalahgunakan kuasa mereka dalam hal diskriminasi harga, menahan buruh dan perilaku lainnya yang menyalahi moral kemanusiaan.

b. Dasar hukum Corporate Social Responsibility (CSR)

CSR sebagaimana yang telah didefinisakn dalam Undang-Undang No. 40 Tahun 2007 tentang Perseroan Terbatas (UUPT), sebagai berikut :

\section{Pasal 1 Angka 3 UUPT}

"Tanggung jawab sosial dan lingkungan adalah komitmen Perseroan untuk berperan serta dalam pembangunan ekonomi berkelanjutan guna meningkatkan kualitas kehidupan dan lingkungan yang bermanfaat, baik bagi Perseroan sendiri, komunitas setempat, maupun masyarakat pada umumnya"

Pasal 74 ayat (1) UUPT

"Tanggung jawab sosial dan lingkungan yang dimaksud dalam UUPT adalah CSR bagi perusahaan atau perseroan tertentu yang menjalankan kegiatan usahanya di bidang dan/atau berkaitan dengan sumber daya alam. Dalam hal ini perusahaan tersebut wajib melaksanakan CSR"

\section{Pasal 74 ayat (2) UUPT}

“Tanggung jawab sosial dan lingkungan sebagaimana dimaksud pada ayat (1) merupakan kewajiban Perseroan yang dianggarkan dan diperhitungkan sebagai biaya Perseroan yang pelaksanaannya dilakukan dengan memperhatikan kepatutan dan kewajaran.

c. CSR adalah komitemen perusahaan untuk mengeliminasi atau meminimalkan setiap efek berbahaya (harmful effects) dalam masyarakat dan memekasimalkan keuntungan jangka panjang. Dengan itu, tujuan dari aktifitas CSR adalah berorientasi pada duniawi yaitu untuk kelangsungan hidup perusahaan.

2. Fungsi Sosial

a. Perintah dalam melaksanakan fungsi sosial berasal dari firman Allah SWT, yaitu seperti yang dijelaskan pada Al-qur'an surat Al-qashash ayat 77 :

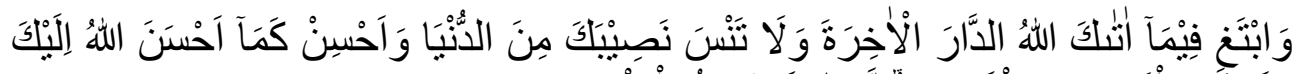

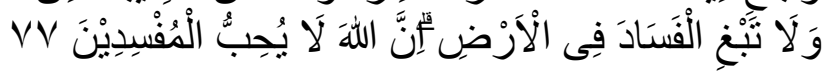

Artinya : "Dan, carilah pada apa yang telah dianugerahkan Allah kepádamu (pahala) negeri akhirat, tetapi janganlah kamu lupakan bagianmu di dunia. Berbuat baiklah (kepada orang lain) sebagaimana Allah telah berbuat baik kepadamu dan janganlah kamu berbuat kerusakan di bumi. Sesungguhnya Allah tidak menyukai orang-orang yang berbuat kerusakan."

Berdasarkan arti dari QS Al-Qashash ayat 77 ini memeiliki 3 makna yaitu yang pertama jika seseorang diberkan anugerah oleh Allah dari segi 
kekayan hata serta nikmat yang banya maka hendakhlah untuk memanfaatkannya di jalan Allah serta mesti patuh pada perintah-Nya sehingga memperoleh paha di dunia dan akhirat nanti, yang kedua setiap orang yang diperkenakan untuk tidak menginggalkan kesenangan dunia yang tidak bertentangan dengan ajaran Allah maka baik Allah, diri sendiri maupun keluarga berhak mempunyai ha kata sesorang yang harus dilaksanakannya, yang ketiga setip orang dianjurkan untuk selalu berbuat baik terhadap sesame sebagaimana Allah selalu berbuat baik kepadanya seperti membantu kesulitan orang lain dan menjalin silaturahi, dan yang terakhir setiap orang yang ada dimuka bumi dilarang berbuat kerusakan di atas bumi atas yang telah Allah ciptakan. Sesungguhanya Allah tidak menyukai orang orang yang membuat kerusakan dan mencintai orang yang berbuat kebaikan dan membantu kesussahan orang lain.

b. Dasar hukum fungsi sosial di Koperasi Syariah terdapat pada :

- PERMEN RI No.7 Tahun 2021 tentang Kemudahan, Perlindungan, Dan Pemberdayaan Koperasi Dan Usaha Mikro, Kecil, Dan Menengah Pasal 15 ayat 2 :

"Koperasi syariah dapat menjalankan fungsi sosial dalam bentuk baitul maal untuk pemberdayaan sosial ekonomi anggota dan masyarakat berdasarkan ketentuan peraturan perundang-undangan”.

- PERMEN RI No.7 Tahun 2021 tentang Kemudahan, Perlindungan, Dan Pemberdayaan Koperasi Dan Usaha Mikro, Kecil, Dan Menengah Pasal 15 ayat 3 :

"Koperasi yang menjalankan usaha simpan pinjam dan pembiayaan syariah dapat menjalankan fungsi sosial dalam bentuk pemberdayaan sosial ekonomi anggota dan masyarakat sesuai dengan ketentuan peraturan perundang-undangan".

c. Tujuan dari fungsi sosial adalah sebagai bentuk penghambaan kepada Allah SWT yang merupakan suatu bentuk pertanggung jawaban sebagai manusia/hamba Allah SWT yang telah memiliki harta berkecukupan untuk bersedia berbagi rezeki dan kebahagiaan kepada orang lain agar kehidupannya bisa mencapai suatu idrak shilah billah (kedekatan hubungannya dengan Allah SWT karena mendapatkan ridho-Nya)

\section{METODOLOGI PENELITIAN}

\section{Metode Yang Digunakan}

Metode yang digunakan dalam penelitian ini adalah studi kasus (case study), yang mana metode tersebut merupakan salah satu metode penelitian yang berfungsi sosial untuk mendeskripsikan suatu fenomena khusus maupun general dengan spesifik, bertujuan untuk mendapatkan hasil deskripsi atau gambara data khusus maupun general (Rusidi, Ami, 2016) yang menekan pada penelitian deskriptif dan menggunakan pendeketan kualitatif

\section{Data Yang Diperlukan}

Sumber data penulisan yang diperlukan adalah sebagai berikut :

1) Sumber Primer 
Sumber data primer yakni sumber penelitian yang dijadikan sebagai sumber informasi peneliti dengan menggunakan alat pengukur atau pengambilan data secara langsung atau yang dikenal dengan istilah interview (wawancara) .Dalam hal ini subjek penelitian yang dimaksud adalah Bendahara Pengurus di Koperasi Baitul Maal Dana Akhirat Arjasari Bandung.

2) Sumber Sekunder

Sumber data sekunder yaitu sumber data pendukung yang berasal dari buku, maupun litelatur lain yang meliputi :

1. Buku Tentang Lembaga Keuangan Syariah.

2. Jurnal tentang Pengehimpunan, Pengelolaan, Dan Pendistribusian Dana Zakat, Infaq, Shadaqah, dan Dana Sosial

3. Data Tertulis dari Buku RAT KBMT Dana Akhirat Arjasari Bandung.

\section{Sumber Data}

Pada identifikasi masalah perlu mengetahui kondisi pengelolaan zakat, infaq, dan dana sosial mulai dari penghimpunan dengan cara menganalisis penghimpunan dan juga sumbernya darimana saja

\section{Teknik Pengumpulan Data}

1) Observasi, yaitu dengan melakukan pengamatan langsung ke tempat penelitian untuk melihat fenomena yang terjadi sesuai dengan penelitian.

2) Wawancara, yaitu melakukan Tanya jawab secara langsung yang dilakukan dengan informan yanga ada di KBMT Dana Akhirat Arjasari Bandung.

3) Studi Kepustakaan, yaitu mengumpulkan data dengan cara penulis memperoleh kepustakan dari teori serta pendapat para ahli dari beberapa buku jurnal referensi yang ada hubungannya dengan penelitian.

\section{Rancangan Analisis Data}

1) Untuk menjawab identifikasi masalah yang pertama yaitu Bagaimana pola penghimpunan zakat, infaq dan dana sosial di koperasi syariah sebagai implementasi fungsi sosial (Studi kasus di KMBT Dana Khirat Arjasari Bandung) melihat dari cara menghimpun dan sumber dana zakat, infaq, dan dana sosial yaitu dengan menggunakan metode deskriptif.

2) Untuk menjawab identifikasi masalah yang ketiga, yaitu Apa Saja Peluang dan Tantangan Dalam Penghimpunan Zakat, Infaq dan Dana Sosial di Koperasi Baitul Maal Wat Tamwil Dana Akhirat Arjasari Bandung, dengan cara mewawancarai informan lalu kemudian di analisis dengan menggunakan analisis SWOT.

\section{Tempat/Lokasi Penelitian}

Penelitian ini dilaksanakan di Koperasi Baitul Maal Wat Tamwil Arjasari Bandung, Jalan. Arjasari KM 08 No.03, rt 03/rw 06 Desa Arjasari, Kecamatan Arjasari Kabupaten Bandung 40379. 


\section{PEMBAHASAN}

\section{A. Strategi Penghimpunan Zakat, Infaq dan Dana Sosial di KBMT Dana Akhirat Arjasari Banjaran Bandung}

Dalam penghimpunan zakat di KBMT Dana Akhirat Arjasari Banjaran Bandung ini masih belum menghimpun dan mengelola dana zakat dari pihak eksternal karena KBMT Dana Akhirat Arjasari Banjaran Bandung belum mempunyai legalitas dari BAZNAS dan LAZNAS untuk menjadi UPZ. Sehingga KBMT Dana Akhirat Arjasari Banjaran Bandung lebih mengoptimalkan penghimpunannya dari pihak internal. Dengan itu, pernyatan dari Permen Nomor 7/Per/Dep.6/IV/2016 tentang Pedoman Penilaian Kesehatan KSPPS Dan USPPS yang diharuskan untuk menerapkan prinsip syariah dengan mengeluarkan zakat sebagai salah satu entitas syariah. Sehingga KBMT Dana Akhirat Arjasari Banjaran Bandung meskipun belum menjadi UPZ, tetapi dapat mengelola zakat yang masih menghimpun zakat dari pihak internal saja yang menjadi salah satu syarat pengeluaran dari zakat perusahaan atau dari BMTnya sendiri, sebagai lembaga keuangan syariah yang telah mencerminkan terpenuhinya dalam menjalankan salah satu prinsip syariah tersebut.

Strategi penghimpunan dana zakat, infaq, dan dana sosial di KBMT Dana Akhirat Arjasari Banjaran Bandung, sebagai berikut :

1. Zakat

Dana zakat yang dihimpun di KBMT Dana Akhirat Arjasari Banjaran Bandung berasal dari 2,5\% pendapatan koperasi pertahun.

2. Infaq

Dana Infaq yang dihimpun bersumber dari pengurus, karyawan, dan anggota KBMT Dana Akhirat Arjasari Banjaran Bandung dengan sukarela.

Berikut adalah jumlah data pengimpunan dana zakat, infaq pada tahun 2016-2020 :

Tabel 1. Tabel Penghimpunan Zakat dan Infaq KBMT Dana Akhirat Arjasari Banjaran Bandung Pada Tahun 2016-2020

\begin{tabular}{ccc}
\hline TAHUN & KETERANGAN & PENGHIMPUNAN \\
\hline \multirow{2}{*}{2016} & Zakat & Rp.15.440.267,43 \\
& Infaq & Rp.33.741.500,00 \\
2017 & Zakat & Rp.43.389.122,50 \\
& Infaq & Rp.34.177.200,00 \\
2018 & Zakat & Rp.43.786.000,00 \\
& Infaq & Rp.32.657.100,00 \\
2019 & Zakat & Rp.43.575.300,00 \\
& Infaq & Rp.31.885.900,00 \\
2020 & Zakat & Rp.45.746.000,00 \\
& Infaq & Rp.28.930.300,00 \\
\hline \multirow{2}{*}{ Sumber : Buku Laporan RAT KBMT Dana Akhirat Arjasari } \\
\multicolumn{2}{c}{ Banjaran Bandung Tahun 2016-2020 }
\end{tabular}




\section{Dana Sosial}

Dana Sosial yang dihimpun yaitu sesuai dengan Anggaran Dasar KBMT Dana Akhirat Arjasari Banjaran Bandung yang telah tercatat yaitu dana sosial hanya diambil dari 5\% SHU/SPA pertahunnya dan tidak ada sumber lainnya seperti dari sanksi atau denda yang dikenakan kepada nasabah yang terlambat dalam pembayaran (ta'zir).

Berikut adalah jumlah data pengimpunan dana sosial pada tahun 2016-2020:

Tabel 2. Tabel Penghimpunan Dana Sosial KBMT Dana Akhirat Arjasari Banjaran Bandung Pada Tahun 2016-2020

\begin{tabular}{|c|c|c|}
\hline TAHUN & PERHITUNGAN & $\begin{array}{c}\text { PENGHIMPUNAN DANA } \\
\text { SOSIAL }\end{array}$ \\
\hline 2016 & $\begin{array}{c}\text { Rp. } 617.610 .697,30 \times 5 \%= \\
\text { Rp.30.880.534,87 }\end{array}$ & Rp.25.342.324,69 \\
\hline 2017 & $\begin{array}{c}\text { Rp. } 837.781 .317,37 \times 5 \%= \\
\text { Rp.41.889.065,87 }\end{array}$ & Rp.30.880.534,87 \\
\hline 2018 & $\begin{array}{c}\text { Rp. } 721.500 .543,75 \times 5 \%= \\
\text { Rp.36.075.027,19 }\end{array}$ & Rp.41.889.065,87 \\
\hline 2019 & $\begin{array}{c}\text { Rp. } 768.007 .806,06 \times 5 \%= \\
\text { Rp.38.400.390,30 }\end{array}$ & Rp.36.075.027,19 \\
\hline 2020 & $\begin{array}{c}\text { Rp. } 847.388 .931,07 \times 5 \%= \\
\text { Rp.42.369.446,55 }\end{array}$ & Rp.38.400.390,30 \\
\hline
\end{tabular}

Sumber : Buku Laporan RAT KBMT Dana Akhirat Arjasari Banjaran Bandung Tahun 2016-2020

\section{B. Peluang Dan Tantangan Dalam Penghimpunan Zakat, Infaq Dan Dana Sosial Di Koperasi Baitul Maal Wat Tamwil Dana Akhirat Arjasari Banjaran Bandung}

Berikut analisis faktor internal dan faktor eksternal dalam analisis SWOT berdasarkan hasil penelitian mengenai analisis strategi pengelolaan zakat, infaq dan dana sosial sebagai implementasi fungsi sosial di koperasi syariah pada Koperasi Baitul Maal Wa Tamwil Dana Akhirat Arjasari Banjaran Bandung :

Tabel 3. Analisis SWOT Pada Strategi Pengelolaan Zakat, Infaq dan Dana Sosial Pada KBMT Dana Akhirat Arjasari Banjaran Bandung

\begin{tabular}{|c|c|c|}
\hline FAKTOR INTERNAL & $\begin{array}{c}\text { KEKUATAN } \\
\text { (Strenghts) }\end{array}$ & $\begin{array}{c}\text { KELEMAHAN } \\
\text { (Weaknesses) }\end{array}$ \\
\hline & $\begin{array}{l}\text { 1. } \begin{array}{l}\text { Koperasi sudah berbadan } \\
\text { hukum }\end{array} \\
\text { 2. Koperasi memiliki asset } \\
\text { gedung serbaguna untuk } \\
\text { melakukan kegiatan dengan } \\
\text { anggota } \\
\text { 3enyelenggarakan RAT } \\
\text { rutin setiap tahunnya } \\
\text { 4. Hubungan kekeluargaan yang } \\
\text { baik antara sesama pengurus, } \\
\text { pengawas, staf karyawan dan } \\
\text { anggota }\end{array}$ & $\begin{array}{l}\text { 1. Kurangnya SDM } \\
\text { 2. Tidak memilki DPS (Dewan } \\
\text { Pengawas Syariah) } \\
\text { 3. Tidak adanya manjemen } \\
\text { pengelola dana baitul maal } \\
\text { 4. Tidak mempunyai SOP } \\
\text { 5. Koperasi belum } \\
\text { mengoptimalkan teknologi } \\
\text { dan promosi } \\
\text { 6. Kurangnya kerjasama dengan } \\
\text { koperasi syariah lain. } \\
\text { 7. Kurangnya kegiatan sosial } \\
\text { rutin yang produktif. } \\
\text { 8. Kurangnya sosialsisasi } \\
\text { pendidikan perkoperasian } \\
\text { untuk anggota }\end{array}$ \\
\hline
\end{tabular}


FAKTOR EKSTERNAL

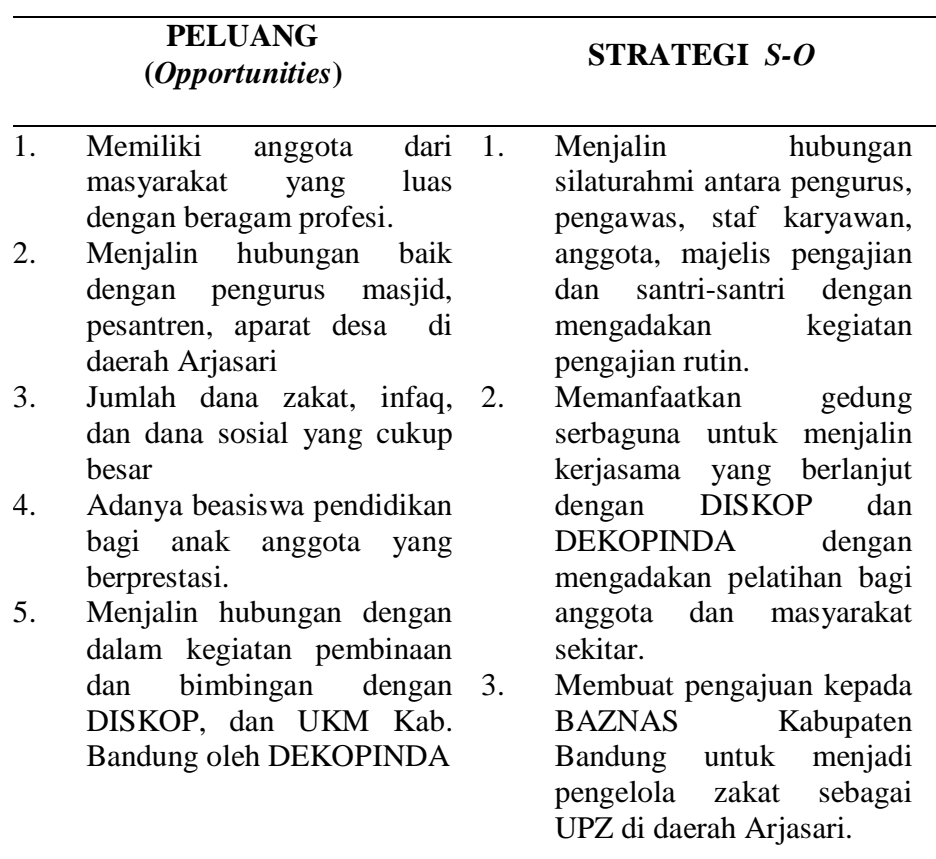

\section{STRATEGI $W-O$}

Mengadakan rekrut staf
karyawan
memberikan kesempatan bagi
masyarakat sekitar khususnya
anak muda yang
berkompeten/anak rari
anggota yang berprestasi
untuk menambah SDM dan
perbaikan manajeman untuk
SDM

2. Koperasi BMT Dana Akhirat Arjasari Banjaran Bandung untuk dapat mengangkat Dewan Pengawas Syariah (DPS), karena sebagai salah satu syarat wajib bagi koperasi syariah.

3. Meningkatkan penggunaan teknologi dalam operasional dan promosi melalui media sosial.

4. Menjalin kerjasama yang luas dengan koperasi syariah lainnya.

5. Memanfaatkan dana zakat, infaq dan dana sosial dengan meningkatkan kegiatan sosial yang rutin dan produktif dengan kerjasama pengurus masjid, pesantren dan aparat desa dalam pemberian manfaat untuk masyarakat yang membutuhkan.

6. Meningkatkan sosialisasi pendidikan perkoperasian kepada anggota dan masyarakat sekitar dengan bantuan DISKOP, dan UKM Kab. Bandung oleh DEKOPINDA serta bimbingan dan pelatihan usaha bagi anggota dan masyarakat yang tidak memiliki penghasilan tetap. 


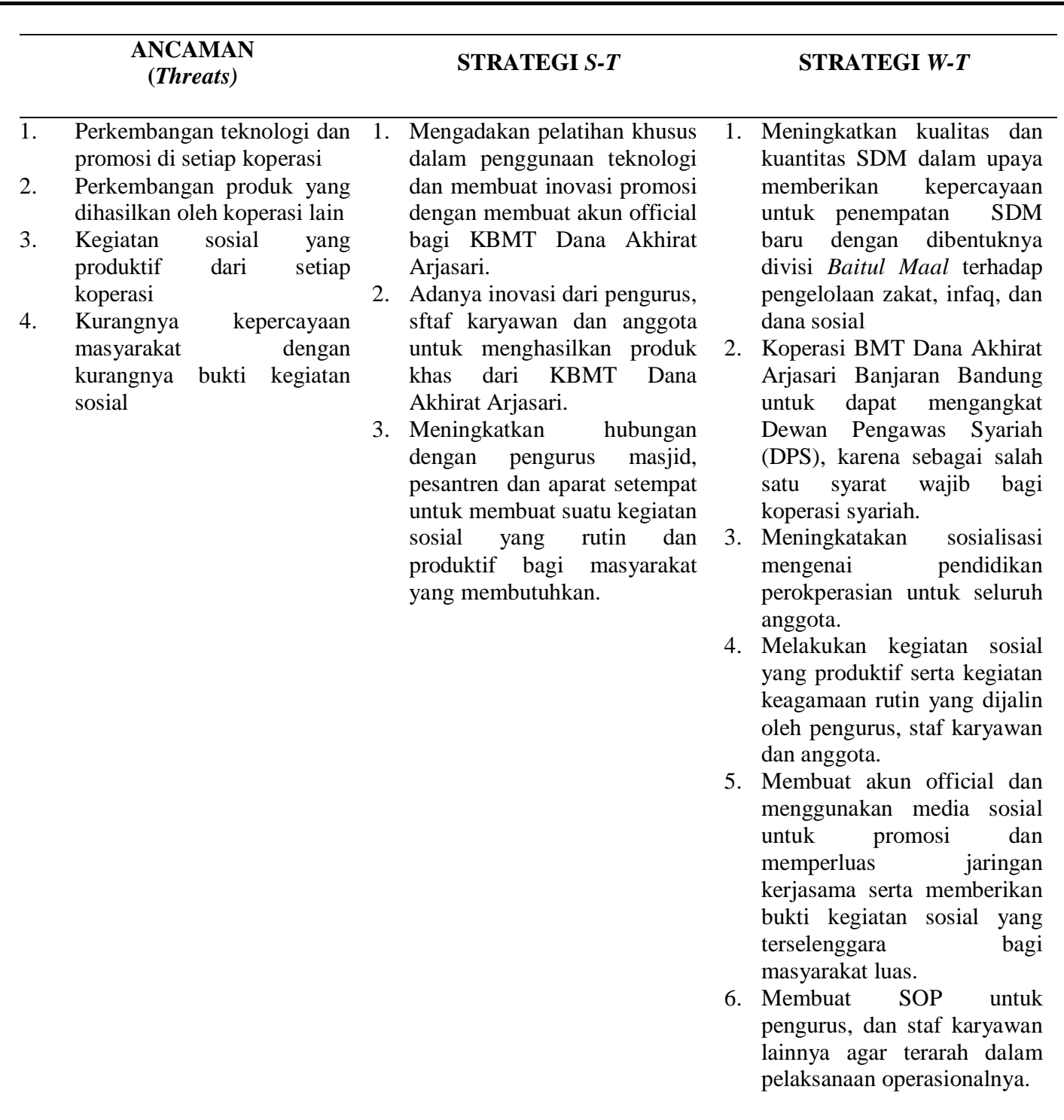

Berdasarkan analisis SWOT yang telah di uraikan di atas, dengan itu peneliti dapat mengambil salah satu strategi yang dapat dijadikan acuan dan cara bagi KBMT Dana Akhirat Arjasari Banjaran Bandung ini untuk menghadapi peluang dan tantangan yang ada dalam mengelola zakat, infaq dan dana sosial sebagai implementasi fungsi sosial koperasi syariah yaitu dengan Kelemahan (Weaknesses) yang dimiliki dengan memanfaatkan dan menggunakan Peluang (Opportunities) yang ada. Selanjutnya dengan menggunakan Kekuatan (Strenghts) yang dimiliki untuk menghadapi tantangan/Ancaman (Threats). Sehingga strategi yang dapat diambil yaitu strategi W-O dan stratetgi S-T

\section{KESIMPULAN DAN SARAN}

\section{A. Kesimpulan}

1. Strategi dari penghimpunan dana zakat, infaq dan dana sosial di KBMT Dana Akhirat Arjasari Banjaran Bandung dilakukan secara sederhana yang masih bersumber dari internal yaitu zakat berasal dari 2,5\% pendapatan koperasi, infaq berasal dari sukarela pengurus, staff karyawan dan anggota, serta dana sosial bersumber dari $5 \%$ SHU 
2. Peluang dan tantangan dalam penghimpunan dana zakat, infaq dan dana sosial di KBMT Dana Akhirat Arjasari Banjaran Bandung yaitu dengan Kelemahan (Weaknesses) yang dimiliki dengan memanfaatkan dan menggunakan Peluang (Opportunities) yang ada . Selanjutnya dengan menggunakan Kekuatan (Strenghts) yang dimiliki untuk menghadapi tantangan/Ancaman (Threats). Sehingga strategi yang dapat diambil yaitu strategi W-O dan stratetgi S-T.

\section{B. Saran}

1. Beradasarkan hasil penelitian, peneliti menyarakan supaya KBMT Dana Akhirat Arjasari Banjaran Bandung mampu meningkatkan strategi penghimpunan dana zakat, infaq dan dana sosial dengan memanfaatkan teknologi seperti media sosial dengan membuat akun official dalam menyebarkan pamflet, agar menambah penghimpunan secara luas.

2. Berdasarkan hasil penelitian, peneliti memberikan saran sebaiknya KBMT Dana Akhirat Arjasari Banjaran Bandung perlu untuk meningkatkan pengelolaan dana zakat, infaq, dan dana sosial, dalam tahap perencanaan, pendistribusian dan pendayagunaan mestinya dengan itu disarankan untuk dibentuknya divisi Baitul Maal sekaligus menyiapkan SDM untuk ditempatkan secara khusus di divisi Baitul Maal ada kegiatan rutin dan produktif bagi masyarakat yang mendapatkan bantuan. Serta perlunya untuk membuat suatu SOP dan target dalam pelaksanaan agar lebih terarah dalam pengelolaannya.

3. Berdasarkan hasil penelitian, peneliti memberikan saran sebaiknya KBMT Dana Akhirat Arjasari Banjaran Bandung Dalam menghadapi peluang dan tantangan yang ada dalam pengelolaan dana zakat, infaq dan dana sosial di KBMT Dana Akhirat Arjasari Banjaran Bandung maka sebaiknya dibentuknya divisi pengelola Baitul Maal, meningkatkan kualitas dan kuantitas SDM dalam upaya memberikan kepercayaan untuk penempatan SDM baru pada divisi Baitul Maal terhadap pengelolaan zakat, infaq, dan dana sosial, membuat akun official dan menggunakan media sosial untuk promosi dan memperluas jaringan kerjasama, meningkatkan hubungan dengan pengurus masjid, pesantren dan aparat setempat untuk membuat suatu kegiatan sosial yang rutin serta produktif bagi masyarakat yang membutuhkan dan sebagai bentuk legalitas khususnya dalam melakukan penghimpunan dana zakat, jika sudah terbentuk divisi baitul maal disarankan untuk menjadi Unit Pengumpul Zakat dari BAZNAS atau LAZNAS.

4. Peneliti menyarankan alangkah lebih baiknya, Koperasi BMT Dana Akhirat Arjasari Banjaran Bandung untuk mengangkat Dewan Pengawas Syariah (DPS) dengan sesuai prosedur KBMT Dana Akhirat Arjasari Banjaran Bandung mengajukan pengangkatan calon DPS dengan meminta rekomendasi dari MUI kota atau kabupaten, karena sebagai salah satu syarat koperasi syariah adalah adanya Dewan Pengawas Syariah sesuai dengan PERMEN Koperasi dan Usaha kecil dan Menengah Republik Indonesia Nomor 16/Per/M.KUKM/IX/2015 tentang pelaksanaan KSPPS yang menjadi salah satu ketentuan umum adanya Dewan Pengawas Syariah yang berfungsi untuk memastikan setiap akad dan produk serta operasional koperasi Syariah sesuai dengan prinsip syariah, sehingga menumbuhkan kepercayaan masyarakat sekitar. 


\section{DAFTAR PUSTAKA}

\section{A. Sumber Utama}

Al-Qur'an Terjemahan Kemenag 2002 (Qur'an in microsoftmword)

\section{B. Peraturan Perundang-Undangan}

PERMEN RI No.7 Tahun 2021 tentang Kemudahan, Perlindungan, Dan Pemberdayaan Koperasi Dan Usaha Mikro, Kecil, Dan Menengah

Permen KUKM Republik Indonesia No. 16 tahun 2015

\section{Buku}

Zuhaily, W. (2010). Fiqih Imam Syafi'i, Terj : M.Afifi, Abdul Hafiz. Jakarta: Niaga Swadaya.

Assauri, S. (2013). Manajemen Pemasaran . jakarta: Rajawali Pers.

Budiman. (2012). Good Governance Pada Lembaga ZISWAF ( Implementasi Pelibatan Pemangku Kepentingan dalam Pengelolaan ZISWAF ),Semarang : Lembaga Penelitian IAIN Walisongo Semarang. Semarang: Lembaga Penelitian IAIN Walisongo Semarang.

Fahrur. (2011). Zakat A-Z Panduan Mudah, Lengkap, dan Praktis tentang Zakat. Solo : Pustaka Mandiri.

Huda, N., \& Heykal, M. (2015). Lembaga Keuangan Islam . Jakarta: KENCANA.

Mardani. (2015). Aspek Hukum Lembaga Keuangan Syariah Di Indonesia. Jakarta: Kencana.

Mardani. (2015). Aspek Hukum Lembaga Keuangan Syariah Di Indonesia. Jakarta: Kencana.

Siti, H. U. (2019). Analisis Pemberlakukan Ta'zir dan Ta'Widh Pada BMT NU Sejahtera Purwokerto. SKRIPSI.

Soemitra, A. (2010). Bank Dan Lembaga Keuangan Syariah. Jakarta: Prenadamedia Group.

Soemitra, A. (2015). Bank \& Lembaga Keuangan Syariah . Jakarta: PRENADAMEDIA GROUP.

Sudarsono, H. (2012). Bank dan Lembaga Keuangan Syariah Deskripsi dan Ilustrasi. Yogyakarta: Ekonisia.

\section{Sumber Lainnya}

Atmoko, T. P. H. (2018). STRATEGI PEMASARAN UNTUK MENINGKATKAN VOLUME PENJUALAN DI CAVINTON HOTEL YOGYAKARTA. Of Indonesian Tourism, Hospitality and Recreation, 1(2), 83-96.

Dasuki, R. E. (2018). KAJIAN GOOD CORPORATE GOVERNANCE PADA KOPERASI SIMPAN PINJAM DAN PEMBIAYAAN SYARIAH. Festival Riset Ilmiah Manajemen Dan Akuntansi Tahun 2018 (FRIMA-2018), 53(9), 1689-1699.

Gumilang, R. C. (2020). TINJAUAN HUKUM ISLAM TERHADAP KEABSAHAN PEMBAYARAN ZAKAT YANG DILAKUKAN SECARA ONLINE YANG 
BERAFILIASI DENGAN BAZNAS MENURUT IMAM SYAFI'I. Journal of Chemical Information and Modeling.

Hedynata, M. L., \& Radianto, W. E. D. (2016). Strategi Promosi Dalam Meningkatkan Penjualan Luscious Chocolate Potato Snack. Manajemen Dan Start-Up Bisnis, 1(1), 20-25.

Nafik, M. dan Fauzy, R. (2015). Pengembangan Model Fungsi Sosial Bisnis Islam Berdasarkan Maqashid Syariah Pada Bank Syariah X. Telaah Bsnis, 16(1), 31-46.

Ningsih, D. A., \& Masruroh, A. H. (2018). ANALISIS PERBANDINGAN SISTEM PEMBERIAN KREDIT PADA KOPERASI SYARIAH DAN KOPERASI KONVENSIONAL. PETA, 3(1).

Nurjamil, \& Nurhayati, S. (2020). Prospek Pengelolaan Dana Filantropi Melalui Baitul Maal Kampus Ikopin. Jurnal Tabarru': Islamic Banking and Finance, 3(2), 185196. https://doi.org/10.25299/jtb.2020.vol3(2).5763

Putra, T. W. (2019). Penghimpunan Dana Zakat Infak Dan Sedekah Di Badan Amil Zakat Nasional. Laa Maisyir, 6(2), 247.

Rawla, P., Sunkara, T., Gaduputi, V., Jue, T. L., Sharaf, R. N., Appalaneni, V., Anderson, M. A., Ben-Menachem, T., Decker, G. A., Fanelli, R. D., Fukami, N., Ikenberry, S. O., Jain, R., Khan, K. M., Krinsky, M. L., Malpas, P. M., Maple, J. T., Fisher, D., Hwang, J. H., ... Abbas KS, Madbouly KM, Abbas MAS, E. D. A. (2018). MANAJEMEN PENGELOLAAN DANA SOSIAL BAITUL MAAL DI KSPPS BMT BINA UMAT MANDIRI KOTA TEGAL DALAM MENSEJAHTERAKAN KAUM DHUAFA. Gastrointestinal Endoscopy.

Rusnee, D., \& Oktafia, R. (2018). PERAN KOPERASI DALAM MENINGKATKAN KESEJAHTERAAN EKONOMI MASYARAKAT DITINJAU DARI HUKUM EKONOMI ISLAM. 1-10.

Sanwani, Herwanti, T., \& Jufri, A. (2017). STRATEGI PENGHIMPUNAN DAN PENYALURAN DANA PADA BAITUL MAAL WAT TAMWIL (BMT) ALHIDAYAH DI KABUPATEN LOMBOK TIMUR. Iqtishoduna, 6(1), 34-64.

Sanwani, Titiek Herwanti, \& Akhmad Jufri. (2017). Strategi Penghimpunan Dan Penyaluran Dana Pada Baitul Maal Wat Tamwil. Al Masraf: Jurnal Lembaga Keuangan Dan Perbankan.

Yuditya, A. R. (2015). Identifikasi Fungsi Sosial dan Komersial Baitul Mal Wa Tamwil (BMT) UGT Sidorigi Capem Belimbing dalam Meminimalisir Rentenir di Pasar (Studi Kasus Pasar Belimbing). Jurnal Ilmiah. 